\title{
Demography AND EQUITY PREMIUM
}

\author{
Wolfgang Kuhle
}

$157-2008$

(c) Mea-Mannheim Research Institute for the Economics of Aging 


\section{Demography and Equity Premium[1}

\section{Wolfgang Kuhle ${ }^{2}$}

This article comprises a tractable two-generations-overlapping, stochastic, neoclassical production economy, where government bonds are in positive net supply. In this framework we show that the entrance of larger (smaller) cohorts into the labor market will lead to an increase (decrease) in the risky and the riskless rate and to an increase (decrease) in the expected equity premium.

\section{Introduction}

The question of how the entrance of smaller cohorts into the labor market will affect the equity risk premium over the coming decades has recently attracted widespread attention. However, little consensus has been reached so far. While Brooks (2002) and Geanakoplos et al. (2004) project a decrease in the equity premium for the coming decades, Brooks (2004) and Börsch-Supan et al. (2007) project an increase in the equity premium for that period. Contrary to these previous studies, which were based purely on computational models and yielded conflicting evidence, the current article will present a tractable, two-generations-overlapping neoclassical growth model in Section 2. This model will be a modified version of the Diamond (1965) framework and is therefore related to the recent contributions of Abel (2001) and Abel (2003) $!^{3}$ Our framework will underline the link between the growth rate of population and the rate of return to capital by means of a general concave production technology. On the side of the

\footnotetext{
${ }^{1}$ I would like to thank Axel Börsch-Supan, Klaus Jaeger, Alexander Ludwig and Edgar Vogel for helpful discussion. Financial support by the U.S. Social Security Administration through grant \#10 $P-98363-1-04$ to the National Bureau of Economic Research, the State of Baden-Württemberg and the German Insurers Association (GDV) is gratefully acknowledged.

${ }^{2}$ Department of Economics, University of Mannheim, MEA Mannheim, L 13, 68131 Mannheim; e-mail:wkuhle@mea.uni-mannheim.de

$\sqrt[3]{\text { Abel }(2001)}$ focuses on a policy of exploiting the equity premium by means of a social security trust fund diversification into equity in an economy where the risky rate of return is exogenously given and population is stationary. Abel (2003) examines the implications of a high realization of a stochastic birth rate with respect to the price of capital in an economy where utility, production and adjustment costs are Cobb-Douglas.
} 
household we will emphasize the portfolio choice behavior by using an Epstein and Zin (1989) utility function. A further characteristic feature of this model is that safe (government) debt will not be in zero net supply. It will be issued by a government rather than the households. Subsequently, Section 3 deals with the consequences of the entrance of a small/large cohort into the labor market. Section 4 concludes.

\section{The Model}

\subsection{Technology and factor prices}

The economy is inhabited by overlapping generations who live for two periods; one period of work is followed by one period of retirement. During the first period of life, each individual supplies one unit of labor inelastically and population evolves according to:

$$
N_{t+1}=\left(1+n_{t}\right) N_{t}
$$

where $N_{t}$ is the size of the cohort born at time $t$ and $1+n_{t}$ is the number of children raised by each member of cohort $t$.

Production is characterized by a continuous, concave, constant returns to scale, aggregate production function $F\left(K_{t}, N_{t}\right)$. This production process is subject to an aggregate technology shock $z_{t}$, which follows a log-normal distribution. Furthermore we assume that this shock is on average neutral. Per capita output $y_{t}$ is therefore given by:

$$
y_{t}=z_{t} f\left(k_{t}\right) ; \quad f^{\prime}()>0, \quad f^{\prime \prime}()<0, \quad E\left[z_{t}\right]=1, \quad \forall t .
$$

Once the respective realization of the shock $z_{t}$ is known, each firm will rent capital and hire labor up to the point where the respective marginal products are equal to the market prices:

$$
\begin{aligned}
& R_{t}=z_{t} \frac{\partial F\left(K_{t}, N_{t}\right)}{\partial K_{t}}=z_{t} f^{\prime}\left(k_{t}\right), \\
& w_{t}=z_{t} \frac{\partial F\left(K_{t}, N_{t}\right)}{\partial N_{t}}=z_{t}\left(f\left(k_{t}\right)-f^{\prime}\left(k_{t}\right) k_{t}\right) .
\end{aligned}
$$




\subsection{Government Debt}

Contrary to the conventional approach, where safe debt/consumption loans are issued by the households (zero net supply), we will take note of the fact that the government is the only entity that can supply safe debt. The budget constraint of the government is given by:

$$
B_{t}+N_{t} \tau_{t}=r_{t} B_{t-1},
$$

where $B_{t-1}$ is the amount of outstanding and $B_{t}$ the amount of newly issued debt in period $t$. Lump sum taxes are denoted by $\tau_{t}$. The rate of interest on government debt which was issued at time $t-1$ is denoted by $r_{t}$. This rate of interest earned on government debt is deterministic, i.e. at time $t$ the government issues debt with a guaranteed rate of return $r_{t+1}$. Risk avers individuals will therefore be willing to hold safe debt even if its rate of return is below the expected risky rate. In our model we will assume that the government pursues a Maastricht debt policy, as it is indeed practiced in most European countries. Such a Maastricht policy is characterized by a constant debt output ratio $\beta$ :

$$
\frac{B_{t}}{Y_{t}}=\beta \quad \forall t
$$

Solving (5) for per capita taxes, using (6) and (1), yields:

$$
\tau_{t}=\left(\frac{1}{\left(1+n_{t-1}\right)} r_{t} y_{t-1}-y_{t}\right) \beta
$$

From now on we use (7) to determine per capita taxes $\tau$.

\subsection{Households}

The representative household lives for two periods and supplies labor inelastically in the first period only. Towards the end of the first period the household faces a consumption/saving and a portfolio allocation decision. Preferences over current and future consumption, $c_{t, 1}$ and $c_{t+1,2}$, are described by a simplified Epstein and Zin (1989) utility function:

$$
U_{t}=\ln \left(c_{t, 1}\right)+\frac{\delta}{1-\phi} \ln E_{t}\left[\left(c_{t+1,2}\right)^{1-\phi}\right] ; \quad 0<\phi, \quad 0<\delta<1 .
$$

The utility function in (8) exhibits an elasticity of intertemporal substitution of unity. Hence, the individual savings/consumption decision is independent of the interest rate, since income and substitution effects cancel and precautionary savings neither dampen 
nor amplify private thrift. This assumption is reasonable as long as the (ambiguous) influence of changes in the rate of interest on savings is not too large. This assumption is also necessary to keep the general equilibrium analysis tractable. The crucial advantage of this specification can be seen in the coefficient of relative risk aversion $\phi$ with respect to second period consumption, which allows to study the entire scope of the portfolio choice problem.

Recalling the taxes levied by the government (7), the value of wealth owned by the consumer when young can be written as: $:^{4}$

$$
\Omega_{t}:=w_{t}-\tau_{t}
$$

For given values of lifetime wealth $\Omega$, the individual chooses to hold assets amounting to:

$$
a_{t}:=b_{t}+h_{t},
$$

where $b_{t}$ and $h_{t}$ are the amounts of riskless bonds and risky capital respectively. Denoting the portfolio share of risky assets by $\gamma_{t}=\frac{h_{t}}{a_{t}}$ and the share of riskfree assets by $\left(1-\gamma_{t}\right)=$ $\frac{b_{t}}{a_{t}}$ yields, according to (8) and (9), the following household problem:

$$
\max _{a, \gamma} U_{t}=\ln \left(\Omega_{t}-a_{t}\right)+\delta \ln \left(a_{t}\right)+\frac{\delta}{1-\phi} \ln E_{t}\left[\left(\gamma_{t} R_{t+1}+\left(1-\gamma_{t+1}\right) r_{t+1}\right)^{1-\phi}\right],
$$

with the corresponding first order condition for the optimal portfolio size:

$$
a_{t}=\frac{\delta}{1+\delta} \Omega_{t}
$$

where the propensity to save out of wealth is $\frac{\delta}{1+\delta}$. The portfolio choice is characterized by the familiar implicit condition for $\gamma_{t}$ :

$$
E_{t}\left(\left[\gamma_{t} R_{t+1}+\left(1-\gamma_{t}\right) r_{t+1}\right]^{-\phi}\left(R_{t+1}-r_{t+1}\right)\right)=0
$$

Using a second order Taylor series approximation, Campbell and Viceira (2002) show that the corresponding optimal portfolio share can be approximated as:

$$
\gamma_{t}\left(R_{t+1}, r_{t+1} ; \phi\right)=\frac{E_{t}\left[\ln \left(R_{t+1}\right)\right]-\ln \left(r_{t+1}\right)+\frac{1}{2} \sigma_{t}^{2}}{\phi \sigma_{t}^{2}}=\ln \left(\frac{E_{t}\left[R_{t+1}\right]}{r_{t+1}}\right) \frac{1}{\phi \sigma_{t}^{2}},
$$

\footnotetext{
${ }^{4}$ The individual receives his wage $w_{t}$ after the realization of $z_{t}$ is known. Note also that taxes are known once $z_{t}$ is known.
} 
where $\sigma_{t}^{2}=\operatorname{Var}\left[\ln \left(R_{t+1}\right)\right]=\operatorname{Var}[\ln (z)]$ and $\ln \left(E_{t}\left[R_{t+1}\right]\right)=E_{t}\left[\ln \left(R_{t+1}\right)\right]+\frac{1}{2} \sigma_{t}^{2}$ I $^{5}$ Once the investment opportunities are changing, the individual will adjust his portfolio according to:

$$
\gamma_{r}=\frac{\partial \gamma_{t}}{\partial r_{t+1}}=-\frac{1}{r_{t+1}} \frac{1}{\phi \sigma_{t}^{2}}<0, \quad \gamma_{f^{\prime}}=\frac{\partial \gamma_{t}}{\partial\left(f^{\prime}\left(k_{t+1}\right)\right)}=\frac{1}{E_{t}\left[R_{t+1}\right]} \frac{1}{\phi \sigma_{t}^{2}}>0 .
$$

The decisive property of the portfolio adjustment behavior in 15 is:

$$
-\frac{\gamma_{r}}{\gamma_{f^{\prime}}}=\frac{E\left[R_{t+1}\right]}{r_{t+1}}=\frac{f^{\prime}\left(k_{t+1}\right)}{r_{t+1}}>1, \quad \therefore \quad \frac{d\left(f^{\prime}\left(k_{t+1}\right)\right)}{d r_{t+1}} \quad=-\frac{\gamma_{r}}{\gamma_{f^{\prime}}}>1,
$$

where the expressions in $(16)$ indicate that for positive expected equity premia the share devoted to the risky asset reacts more sensitive with respect to the riskfree rate than the risky rate. Therefore we find that an increase in both rates of return, which leaves the equity premium unchanged, will result in a lower portfolio share in the risky asset.

\subsection{Equilibrium}

Having completed the partial analysis of the firm, the government and the household, we can now turn towards the equilibrium conditions for the bond and equity markets. Capital market clearing requires:

$$
\left(1+n_{t}\right) k_{t+1}=\gamma_{t} \frac{\delta}{1+\delta} \Omega_{t}
$$

The bond market equilibrium condition reads:

$$
y_{t} \beta=\left(1-\gamma_{t}\right) \frac{\delta}{1+\delta} \Omega_{t}
$$

Taken together, equations (17), (18), (14) and (3) define the time path of the capital intensity $k$, the safe rate of return $r$, the optimal portfolio share $\gamma$ and the risky rate $R$. Finally, the resulting expected equity premium $E_{t}\left[\Pi_{t+1}\right]$ is given by:

$$
E_{t}\left[\Pi_{t+1}\right]=E_{t}\left[R_{t+1}\right]-r_{t+1}=f^{\prime}\left(k_{t+1}\right)-r_{t+1}
$$

\section{Baby-Boom and Equity-Premium}

We can now consider the consequences of the entrance of a large/small cohort into the labor market. Taking the current state of the economy $\left(k_{t-1}, k_{t}, z_{t-1}, z_{t}\right)$ as given, we

\footnotetext{
5 The rate of return $R_{t+1}=z_{t+1} f^{\prime}\left(k_{t+1}\right)$ inherits its log-normal distribution from the technology shock $z_{t+1}$. Thus, $\ln \left(R_{t+1}\right)$ follows a normal distribution.
} 
differentiate (17) and (18) with respect to $d n_{t}, d \gamma_{t}, d k_{t+1}$. Hence, once we recall (3) and (14), we have:

$$
\frac{d k_{t+1}}{d n_{t}}=-\frac{k_{t+1}}{\left(1+n_{t}\right)}<0, \quad \therefore \quad \frac{d\left(f^{\prime}\left(k_{t+1}\right)\right)}{d n_{t}}=f^{\prime \prime}\left(k_{t+1}\right) \frac{d k_{t+1}}{d n_{t}}>0
$$

and

$$
\frac{d \gamma_{t}}{d n_{t}}=0, \quad \therefore \quad \gamma_{f^{\prime}} \frac{d\left(f^{\prime}\left(k_{t+1}\right)\right)}{d n_{t}}+\gamma_{r} \frac{d r_{t+1}}{d n_{t}}=0 .
$$

Interpretation of these expressions is straightforward: the expressions in equation (20) indicate that a change in the growth rate of population does not change government taxes (7). Hence the value of life-cycle income $\Omega_{t}$ out of which individuals save a constant fraction remains unchanged. Thus an increase in the relative size of the next cohort lowers the capital intensity and increases the expected future return on risky investments. The expressions in (21) follow from the bond market equilibrium condition. They indicate that, for $\frac{d\left(f^{\prime}\left(k_{t+1}\right)\right)}{d n_{t}}>0$ the government has to offer a higher riskless rate, i.e. $\frac{d r_{t+1}}{d n_{t}}>0$ to sell a given amount of debt. With respect to the expected equity premium 19) we can now use the individual portfolio adjustment behavior described in (16) to show that:

$$
\frac{d\left(E_{t}\left[\Pi_{t+1}\right]\right)}{d n_{t}}=\left(\frac{d\left(f^{\prime}\left(k_{t+1}\right)\right)}{d r_{t+1}}-1\right) \frac{d r_{t+1}}{d n_{t}}=-\left(\frac{\gamma_{r}}{\gamma_{f^{\prime}}}+1\right) \frac{d r_{t+1}}{d n_{t}}>0, \quad \because \quad \frac{\gamma_{r}}{\gamma_{f^{\prime}}}<-1 .(2
$$

Therefore we find that due to the asymmetric portfolio adjustment behavior an increase in the growth rate for population also increases the expected equity premium.

\section{Conclusion}

Motivated by the conflicting results of previous computational studies, we have discussed the causal link between the entrance of smaller cohorts into the labor market and the equity premium in a simple two-generations-overlapping economy. At the expense of closed-form solutions we have chosen a framework with a general neoclassical, concave, production function and a fairly general (CRRA) portfolio adjustment behavior.

In this framework we have then shown that the entrance of a small cohort into the labor market will lead to a lower expected equity premium. While both rates of return fall, the risky rate will fall by more than the riskless rate.

The causal link between the age distribution and the equity premium is indirect. It operates through the capital widening effect that increases the expected risky rate 
and forces the government to offer a higher riskless rate to sell its debt. The resulting increase in the expected equity premium is then solely a consequence of the asymmetric portfolio adjustment behavior, i.e. $\gamma_{f^{\prime}}<\left|\gamma_{r}\right|$.

\section{References}

Abel, A. B. (2001). The effects of investing social security funds in the stock market when fixed costs prevent some households from holding stocks. American Economic Review, 91(1):128-148.

Abel, A. B. (2003). The effects of a baby boom on stock prices and capital accumulation in the presence of social security. Econometrica, 71(2):551-578.

Brooks, R. (2002). Asset-market effects of the baby boom and social-security reform. American Economic Review, 92(2):402-406.

Brooks, R. (2004). The equity premium and the baby boom. Econometric Society Wintermeeting 2004, (155):1-25.

Börsch-Supan, A., Ludwig, A., and Sommer, M. (2007). Aging and asset prices. MEA Discussion Paper, (129):1-75.

Campbell, J. Y. and Viceira, L. M. (2002). Strategic Asset Allocation. Oxford University Press.

Diamond, P. A. (1965). National debt in a neoclassical growth model. American Economic Review, 55(5):1126-1150.

Epstein, L. G. and Zin, S. E. (1989). Substitution, risk aversion, and the temporal behavior of consumption and asset returns: A theoretical framework. Econometrica, 57(4):937-969.

Geanakoplos, J., Magill, M., and Quinzii, M. (2004). Demography and the long-run predictability of the stock market. Cowels Foundation Discussion Paper, (1380R):153.

Samuelson, P. A. (1969). Lifetime portfolio selection by dynamic stochastic programming. Review of Economics and Statistics, 51(3):239-246. 


\section{Discussion Paper Series}

Mannheim Research Institute for the Economics of Aging Universität Mannheim

To order copies, please direct your request to the author of the title in question.

\begin{tabular}{|c|c|c|c|}
\hline Nr. & Autoren & Titel & Jahr \\
\hline $145-07$ & Jürgen Maurer & $\begin{array}{l}\text { Modelling socioeconomic and health } \\
\text { determinants of health care use: A } \\
\text { semiparametric approach }\end{array}$ & 07 \\
\hline $146-07$ & $\begin{array}{l}\text { Jérome Adda, James } \\
\text { Banks, Hans-Martin } \\
\text { von Gaudecker }\end{array}$ & $\begin{array}{l}\text { The Impact of Income Shocks on Health: } \\
\text { Evidence from Cohort Data }\end{array}$ & 07 \\
\hline $147-07$ & $\begin{array}{l}\text { Klaus Jäger, } \\
\text { Wolfgang Kuhle }\end{array}$ & $\begin{array}{l}\text { The Optimum Growth Rate for Population } \\
\text { Reconsidered }\end{array}$ & 07 \\
\hline $148-07$ & $\begin{array}{l}\text { Axel Börsch-Supan, } \\
\text { Ismail Düzgün, } \\
\text { Matthias Weiss }\end{array}$ & $\begin{array}{l}\text { Age and Productivity in Work Teams: Evidence } \\
\text { from the Assembly Line }\end{array}$ & 07 \\
\hline $149-07$ & Matthias Weiss & Sick Leave and the Composition of Work Teams & 07 \\
\hline $150-07$ & Matthias Weiss & Are Age-Diverse Work Teams Better? & 07 \\
\hline $151-07$ & $\begin{array}{l}\text { Alexander Ludwig, } \\
\text { Thomas Schelkle, } \\
\text { Edgar Vogel }\end{array}$ & $\begin{array}{l}\text { Demographic Change, Human Capital and } \\
\text { Endogenous Growth }\end{array}$ & 07 \\
\hline $152-07$ & $\begin{array}{l}\text { Karsten Hank } \\
\text { Stephanie Stuck }\end{array}$ & $\begin{array}{l}\text { Gesellschaftliche Determinanten produktiven } \\
\text { Alterns in Europa }\end{array}$ & 07 \\
\hline $153-07$ & $\begin{array}{l}\text { Axel Börsch-Supan } \\
\text { Christina B. Wilke }\end{array}$ & $\begin{array}{l}\text { Szenarien zur mittel- und langfristigen } \\
\text { Entwicklung der Anzahl der Erwerbspersonen } \\
\text { und der Erwerbstätigen in Deutschland }\end{array}$ & 07 \\
\hline $154-07$ & $\begin{array}{l}\text { Alexander Ludwig, } \\
\text { Alexander Zimper }\end{array}$ & $\begin{array}{l}\text { A Parsimonious Model of Subjective Life } \\
\text { Expectancy }\end{array}$ & 07 \\
\hline $155-07$ & $\begin{array}{l}\text { Alexander Zimper, } \\
\text { Alexander Ludwig }\end{array}$ & Attitude polarization & 07 \\
\hline $156-08$ & $\begin{array}{l}\text { Florian Heiss, } \\
\text { Daniel McFadden, } \\
\text { Joachim Winter }\end{array}$ & $\begin{array}{l}\text { Mind the Gap! Consumer Perceptions and } \\
\text { Choices of Medicare Part D Prescription Drug } \\
\text { Plans }\end{array}$ & 08 \\
\hline $157-08$ & Wolfgang Kuhle & Demography and Equity Premium & 08 \\
\hline
\end{tabular}

